\title{
Parasitism disruption by ants of Anagyrus lopezi (Hymenoptera: Encyrtidae), parasitoid of cassava mealybug
}

\author{
MUHAMMAD ZAINAL FANANI ${ }^{1,2, \vartheta}$, AUNU RAUF ${ }^{3, v,}$, NINA MARYANA ${ }^{3}$, ALI NURMANSYAH ${ }^{3}$, \\ DADAN HINDAYANA ${ }^{3}$ \\ ${ }^{1}$ Entomology Program, School of Graduates, Institut Pertanian Bogor. Jl. Raya Dramaga, Bogor 16680, West Java, Indonesia. `email: \\ muhammaduzainale@gmail.com \\ ${ }^{3}$ Department of Plant Protection, Faculty of Agriculture, Institut Pertanian Bogor. Jl. Meranti, Kampus Dramaga, Bogor 16680, West Java,Indonesia. \\ Tel.: +62-251-8629354, 8629350, "»aunu@indo.net.id
}

Manuscript received: 12 March 2020. Revision accepted: 2 May 2020.

\begin{abstract}
Fanani MZ, Rauf A, Maryana N, Nurmansyah A, Hindayana D. 2020. Parasitism disruption by ants of Anagyrus lopezi (Hymenoptera: Encyrtidae), parasitoid of cassava mealybug. Biodiversitas 21: 2337-2343. Parasitoid, Anagyrus lopezi (De Santis) (Hymenoptera: Encyrtidae) was introduced into Indonesia in 2014 to control the invasive cassava mealybug, Phenacoccus manihoti Matile-Ferrero (Hemiptera: Pseudococcidae). Among ants associated with honeydew-producing hemipterans, there are three common species in Indonesia i.e., Anoplolepis gracilipes (Smith), Dolichoderus thoracicus (Smith), and Oecophylla smaragdina (Fabricius) (Hymenoptera: Formicidae). The objective of this research was to investigate the relative influence of the three ant species on the parasitism of A. lopezi under laboratory conditions. Experiments were carried out by allowing a number of ants and parasitoids to forage on mealybugs-infested waterleaf (Talinum triangulare (Jaqc.) Willd.). The average time spent by individual parasitoid foraging was significantly longer (27.39 minutes) on ant-excluded plants compared to ant-attended plants (2.47- 4.68 minutes). Accordingly, parasitoid spent less time in finding hosts on ant-excluded plants, while spent a longer time in handling hosts. More oviposition activities by parasitoids on mealybug were occurred on ant-excluded plants compared to those on ant-attended plants. As a result, the percentage of parasitism and the number of wasps that emerged from the hosts on ant-excluded plants were almost $2-3$ folds higher than those on ant-attended plants.
\end{abstract}

Keywords: Ants, biological control, biotic interference, cassava mealybug, parasitoid

\section{INTRODUCTION}

During the last ten years, at least three species of mealybugs (Hemiptera: Pseudococcidae) have invaded Indonesia. One of them is the cassava mealybug, Phenacoccus manihoti Matile-Ferrero. The pest is native to South America, but it was accidentally introduced into Africa in early 1970s (Bellotti et al. 2012) and Asia in 2008 (Parsa et al. 2012; Graziosi et al. 2015). The cassava mealybug was first detected in Indonesia in early 2010 (Muniappan et al. 2011). The pest has been found in Java, Sumatera, and Nusa Tenggara and caused heavy damage on cassava (Abduchalek et al. 2017; Wyckhuys et al. 2018a; Fanani et al. 2019). To control the pest, the hostspecific endoparasitoid Anagyrus lopezi (De Santis) (Hymenoptera: Encyrtidae) was introduced from Paraguay to Nigeria in 1981 (Neuenschwander 2001), and subsequently to Thailand in 2009 (Winotai et al. 2010), and to Indonesia in 2014 (Wyckhuys et al. 2014).

Like most of the mealybugs, $P$. manihoti also produces honeydew and establishes a mutualistic relationship with ants (Vilela and Del-Claro 2018). Honeydew is a solution that primarily comprises sugars mixed with various amino acids (Detrain et al. 2010; Mansour et al. 2012). Therefore, honeydew is an attractive food for ants because it satisfies nutritional requirements that are fundamental for colony growth and survival (Hagenbucher et al. 2014; Shik et al.
2014; Novgorodova 2015). In exchange for honeydew, ants provide multiple services that benefit honeydew-producing hemipterans (Tena et al. 2016; Watanabe et al. 2019). Primarily, ants protect hemipteran from natural enemies (Carabali-Banguero et al. 2013; Cheng et al. 2015; Freitas and Rossi 2015). Therefore, many studies have reported that the presence of ants can reduce the effectiveness of parasitoid wasp in controlling insect pests (e.g., Navarrete et al. 2013; Calabuig et al. 2015; Feng et al. 2015; SadeghiNamaghi and Amiri-Jami 2018; Xu et al. 2020).

The level of ant interferences with parasitoids depends on the aggressiveness of the ant species (Mgocheki and Addison 2009). Buckley and Gullan (1991) reported a low parasitism rate $(>15 \%)$ of coccids in the presence of Tapinoma sp. and Iridomyrmex sp., and $<10 \%$ in the presence of the more aggressive Oecophylla sp. or Solenopsis sp. In Indonesia, among ants that are commonly associated with honeydew-producing hemipterans are a yellow crazy ant, Anoplolepis gracilipes (Smith), black cacao ant, Dolichoderus thoracicus (Smith), and weaver ants, Oecophylla smaragdina (Fabricius) (Hymenoptera: Formicidae). Anoplolepis gracilipes is considered as an aggressive ant (Hoffmann 2015), and even more $O$. smaragdina (Forbes and Northfield 2017; Migani et al. 2017), while D. thoracicus may be less aggressive than other species (Chong and Lee 2010). The aim of this study was to examine, under controlled conditions, the relative 
influence of three ant species on the effectiveness of biological control of the cassava mealybug by the parasitoid, A. lopezi. Specifically, we determine the effect of ants on parasitoid oviposition activities, level of parasitism, and behavioral responses of the parasitoid.

\section{MATERIALS AND METHODS}

All experiments were conducted from August 2016 to May 2017 in the Laboratory of Insect Bionomy and Ecology, Faculty of Agriculture, IPB University, Bogor, Indonesia.

\section{Plants for insect mass-rearing}

Cassava cuttings $(15 \mathrm{~cm})$ were grown in transparent polyvinyl chloride (PVC) container $(\mathrm{d}=8 \mathrm{~cm}, \mathrm{~h}=11.5 \mathrm{~cm})$ with $200 \mathrm{~mL}$ of tap water at the base. When cassava cuttings attained 8-10 leaves (about four weeks old), they were used for mass-rearing $P$. manihoti. Waterleaf (Talinum triangulare (Jaqc.) Willd) was utilized as a hostplant. Cassava cuttings $(13-14 \mathrm{~cm})$ were planted in plastic cup $(\mathrm{d}=4 \mathrm{~cm}, \mathrm{~h}=5 \mathrm{~cm})$ filled with tap water. After the waterleaf seedlings had eight leaves, they were used as a host plant for $P$. manihoti during parasitoid-ant experiments. Talinum triangulare has been reported as an alternate host for the cassava mealybug (Essien et al. 2013).

\section{Insect colonies}

A laboratory colony of cassava mealybugs, initiated in 2010 from cassava fields in Bogor, was maintained on cassava seedlings in plastic cages $(1=75 \mathrm{~cm}, \mathrm{w}=50 \mathrm{~cm}, \mathrm{~h}$ $=50 \mathrm{~cm}$ ). Colonies of A. lopezi were started in 2014 and mass-reared using third-instar nymphs of $P$. manihoti. The parasitoid colony was periodically refreshed with fieldcollected insects. The rearing conditions were maintained at $27 \pm 2{ }^{\circ} \mathrm{C}, 60 \pm 3 \%$ relative humidity and photoperiod of 12: $12 \mathrm{~h}$ (L:D).

The yellow crazy ant (A. gracilipes) and black cacao ant (D. thoracicus) colonies were collected from cassava fields, whereas the weaver ant (O. smaragdina) colony was collected from mango trees in Bogor, West Java. The ant colonies were taken carefully to the laboratory and maintained separately in plastic containers $(\mathrm{d}=15 \mathrm{~cm}, \mathrm{~h}=$ $25 \mathrm{~cm}$ ). A barrier of sticky material was applied to the edge of the container to prevent the ants from escaping. Food for A. gracilipes and $D$. thoracicus consisted of diluted honey solution $(20 \%)$ absorbed into a cotton wool ball and placed in a plastic cup $(\mathrm{d}=4.5 \mathrm{~cm}, \mathrm{~h}=6.5 \mathrm{~cm})$. The colonies of $O$. smaragdina were provided with living insects such as caterpillars, larva, and adult dipteran, in addition to honey solution.

\section{Effects of ants on parasitoid residence time and oviposition activities}

Waterleaf seedlings, each with 20 third-instar nymphs of $P$. manihoti, were transferred into cylindrical cages $(\mathrm{d}$ $=10 \mathrm{~cm}, \mathrm{~h}=22.3 \mathrm{~cm})$. Thereafter, 20 worker ants of each species were transferred separately into the cage. Ants and mealybugs were allowed to interact for $3 \mathrm{~h}$. The observation was started when a single mated female wasp was transferred into the experimental cage. The behavior of wasp was observed for $1 \mathrm{~h}$ and included length of time of a parasitoid spent on the plant, length of time searching, and handling hosts. In this study, host-handling time was defined as the sum of adult parasitoid female examination, probing, drilling, and oviposition on a host. The number of ovipositor insertions was also recorded. To determine oviposition success, mealybugs stung by the parasitoids were dissected in phosphate buffer solution (PBS) on object-glass using a pair of microneedles and examined under the Olympus type SZ51 stereo microscope (type WHSZ10X-H/22 lens). The number of parasitoid eggs oviposited in each mealybug was counted. The experiment consisted of ant-tended and ant-excluded treatments, and each was replicated eight times.

\section{Effect of ant on parasitism and wasp sex ratio}

Cassava cuttings each infested with 100 third-instar nymphs of $P$. manihoti were used in this experiment. A total of 100 workers of each ant species were transferred into the experimental cages $(\mathrm{d}=24 \mathrm{~cm}, \mathrm{~h}=55 \mathrm{~cm})$ containing the $P$. manihoti-infested cassava cuttings and allowed to forage for $3 \mathrm{~h}$. Thereafter, five two-day-old female and five male wasps were aspirated from the rearing cages and then gently introduced into the experimental cages. An ant-free cage with $P$. manihoti and A. lopezi only was included as a control. After $24 \mathrm{~h}$ exposure, both ants and parasitoid wasps were removed. Cages with exposed $P$. manihoti nymphs were then allowed to stand for 10 days, after which the total number of mummies was counted. The parasitoids within mummies were allowed to develop further, and the number of emerged wasps was recorded. The sex ratio was calculated as the proportion of the females to the total number of emerged wasps. The experiment was replicated eight times.

\section{Observation on the behavior of ants and wasps}

A single waterleaf seedling infested with 50 third-instar nymphs of the cassava mealybug was placed inside transparent plastic cylindrical $(\mathrm{d}=10, \mathrm{~h}=22.3 \mathrm{~cm})$ insectrearing cage. Thereafter, 50 worker ants of each species were transferred separately into the cage and allowed to forage for $1 \mathrm{~h}$. Five two-day-old mated A. lopezi were then introduced into the cages. Observations were made soon after the release of the parasitoids where the behavior of ants and parasitoids on plants were recorded at 10 minutes intervals for $1 \mathrm{~h}$. Behavioral responses of A. lopezi toward worker ants were classified into four categories (Liere and Perfecto 2008; Tanga et al. 2016): (i) fly away when encountering an ant, (ii) jump away from ants on encounter, (iii) change of walking direction to avoid of physical contact with ants, and (iv) ignore ants on the encounter. Ant response toward parasitoid wasps was also recorded. This experiment was replicated eight times.

\section{Data analysis}

All data on the effect of three ant species on parasitoid oviposition activities, parasitism rate, and the number of 
wasps emerged, and sex ratio was subjected to one-way analysis of variance (ANOVA). The homoscedasticity and normality of the data were firstly checked using the analytic method of Shapiro-Wilk. Data on the number of ovipositor insertions were transformed $\sqrt{\mathrm{Y}}+0.5$. The means were compared using Tukey's Studentized Range (HSD) test at the $\alpha$ level $(\mathrm{p}<0.05)$ to indicate significance. All statistical data analyses were conducted with SAS version 9.4 (SAS 2015).

\section{RESULTS AND DISCUSSION}

\section{Effects of ants on parasitoid residence time and oviposition activities}

The presence of ants significantly affected $\left(\mathrm{F}_{3,31}=3.94\right.$; $\mathrm{P}<0.001)$ residence time of parasitoids in the plants. In antexcluded treatment, the parasitoid remained in plants for 27 minutes without having interference from the ants (Table 1). In ant-present treatment, the residence time of parasitoid in the plants was much shorter (4-6 minutes), as a result of ant interference. Our laboratory observation indicated when encountered by ants, parasitoids usually flew away onto the wall of the treatment cage, but several minutes later they came back to the plant to look for the mealybugs. Liere and Perfecto (2008) reported that parasitoid Homalotylus shuvakhinae Trjapitzin spent a significantly shorter time on plants with ants than in the plants without ants. Similarly, Beltra et al. (2015) reported that the presence of ants Lasius grandis Forel on plants reduced the time spent by Acerophagus cf. cocois, a parasitoid of Phenacoccus peruvianus Granara de Willink.

Table 1. Length of time ( $x \pm$ SE) of parasitoids spent in plants, finding hosts, and handling hosts during 1-h exposure under antpresent and ant-excluded treatments

\begin{tabular}{lccc}
\hline & \multicolumn{3}{c}{ Duration (minutes) } \\
\cline { 2 - 4 } Treatment & Spent in plants & $\begin{array}{c}\text { Spent finding } \\
\text { host }\end{array}$ & $\begin{array}{c}\text { Spent } \\
\text { handling } \\
\text { hosts }\end{array}$ \\
\hline Ant-excluded & $27.39 \pm 3.84 \mathrm{a}^{*}$ & $7.44 \pm 1.48 \mathrm{a}$ & $4.30 \pm 0.49 \mathrm{a}$ \\
A. gracilipes & $4.03 \pm 1.65 \mathrm{~b}$ & $44.64 \pm 6.92 \mathrm{~b}$ & $1.34 \pm 0.58 \mathrm{~b}$ \\
D. thoracicus & $5.57 \pm 1.16 \mathrm{~b}$ & $24.63 \pm 5.17 \mathrm{c}$ & $1.71 \pm 0.37 \mathrm{~b}$ \\
O. smaragdina & $3.72 \pm 1.05 \mathrm{~b}$ & $23.55 \pm 4.47 \mathrm{c}$ & $0.83 \pm 0.23 \mathrm{~b}$ \\
\hline
\end{tabular}

*Different alphabets within the same column are significantly different at $\mathrm{p} \leq 0.05$
Insect parasitoids need time to find, handle, and oviposit on their hosts (Heidari and Jahan 2000). If this searching or handling time is interrupted, the parasitism success might be significantly reduced (Liere and Perfecto 2008). In our laboratory experiment, the presence of ants showed a significant effect $\left(\mathrm{F}_{3.31}=1.81 ; \mathrm{P}<0.001\right)$ on the length of time spent by the parasitoids in finding host. The average time spent by a parasitoid to find the host was shorter in ant-excluded treatment than those in ant-present treatment. In ant-excluded treatment, parasitoid spent 7 minutes to find the hosts, whereas in ant-present treatment ranged 24 to 45 minutes (Table 1). There was no significant difference in length of time in finding hosts by parasitoids between $D$. thoracicus and $O$. smaragdina attended plants. However, parasitoid significantly took longer (45 minutes) to find hosts in plants attended with $A$. gracilipes. Our laboratory observations indicated that $A$. gracilipes were very active in harvesting honeydew from the mealybugs, causing more disruption to the parasitoids. The presence of ants in host plants also significantly affected $\left(\mathrm{F}_{3.31}=3.41 ; \mathrm{P}=0.008\right)$ duration of host handling by parasitoid. In ant-excluded treatment, parasitoid spent a longer time (4 minutes) handling hosts compared to those in ant-present treatment (1-2 minutes).

The length of time spent on host handling by parasitoid affected oviposition activities. The presence of ants significantly affected $\left(\mathrm{F}_{3.31}=3.94 ; \mathrm{P}=0.004\right)$, the number of ovipositor insertions and eggs laid by female parasitoids. In ant-excluded treatment, the average number of ovipositor insertions of parasitoids was 7.37 stings, which was higher than in ant-present treatments (1.12-2.75 stings) (Table 2). The number of ovipositor insertions was reflected by the number of eggs successfully laid in each treatment. There was a highly significant difference $\left(\mathrm{F}_{3.31}=\right.$ 3.94; $\mathrm{P}=0.004$ ) of the number of eggs laid by the parasitoid on the host between ant-excluded and antpresent treatments. The average number of eggs laid was 11.37 in ant-excluded treatments as compared to 1.37-2.37 in ant-present treatments. Accordingly, percentage of superparasitism was significantly higher $\left(\mathrm{F}_{3.31}=3.49 ; \mathrm{P}=\right.$ $0.008)$ in ant-excluded plants $(13.75 \%)$ as compared to those in ant-present plants $(1.25-3.12 \%)$. It has been reported that superparasitism is common in parasitoid $A$. lopezi, especially when the female oviposited on the third instar nymphs of the cassava mealybug (Adriani et al. 2016)

Table 2. Number $(\mathrm{x} \pm \mathrm{SE})$ of ovipositor insertion, eggs laid, and rate of superparasitism by A. lopezi after $24 \mathrm{~h}$ exposure period to third instar nymphs of $P$. manihoti in ant-present and ant-excluded treatments

\begin{tabular}{lcccc}
\hline Treatment & No. of mealybugs offered & No. of ovipositor insertion & No. of eggs laid & Superparasitism rate $(\%)$ \\
\hline Ant-excluded & 20 & $7.37 \pm 0.90 \mathrm{a} *$ & $11.37 \pm 1.80 \mathrm{a}$ & $13.75 \pm 3.50 \mathrm{a}$ \\
A. gracilipes & 20 & $1.12 \pm 1.72 \mathrm{~b}$ & $1.37 \pm 0.61 \mathrm{~b}$ & $1.25 \pm 0.81 \mathrm{~b}$ \\
D. thoracicus & 20 & $2.75 \pm 0.52 \mathrm{~b}$ & $2.37 \pm 0.53 \mathrm{~b}$ & $3.12 \pm 1.31 \mathrm{~b}$ \\
O. smaragdina & 20 & $1.25 \pm 0.59 \mathrm{~b}$ & $1.75 \pm 0.64 \mathrm{~b}$ & $1.25 \pm 1.05 \mathrm{~b}$ \\
\hline
\end{tabular}

*Different alphabets within the same column are significantly different at $\mathrm{p} \leq 0.05$ 


\section{Effect of ants on parasitism rate and wasp emergence}

The parasitism rate of $P$. manihoti by $A$. lopezi was significantly higher $\left(\mathrm{F}_{3.31}=57.77 ; \mathrm{P}<0.001\right)$ in the antexcluded treatment, averaging $61.25 \%$ compared with less than $40 \%$ in the ant-present treatments (Figure 1). The lowest level of parasitism $(22.25 \%)$ was found in the treatment of $O$. smaragdina, significantly different from those of $A$. gracilipes and D. thoracicus. Our studies revealed that the effectiveness of parasitoid $A$. lopezi was decreased in the presence of each of the three ant species, indicated by a lower rate of parasitism. The lower percentage of parasitism in the presence of ants can be attributed to a shorter time available for handling host (see Table 1, column 4). This is in agreement with other studies that showed a strong correlation between rapid hosthandling with reduced success on an-attended treatment (Mgocheki and Addison 2009; Heidari and Jahan 2000; Tanga et al. 2016). In addition to parasitism, various species of parasitoid cause mortality through host feeding and mutilation (Cebolla et al. 2018; Kaser et al. 2018; Jia and Liu 2018) termed as non-reproductive mortality (Abram et al. 2019). Parasitoid, A. lopezi, has been reported to cause such mortality to the host (Neuenschwander and Madojemu 1986). In this regard, although we did not investigate the effect of ant attendance on non-reproductive mortality, Martinez-Ferrer et al. (2003) have clearly demonstrated that mortality of red scale Aonidiella aurantii Maskell (Hemiptera: Diapididae) due to host feeding and mutilation by parasitoid Comperiella bifasciata Howard and Aphytis melinus DeBach was diminished by the presence of ants.

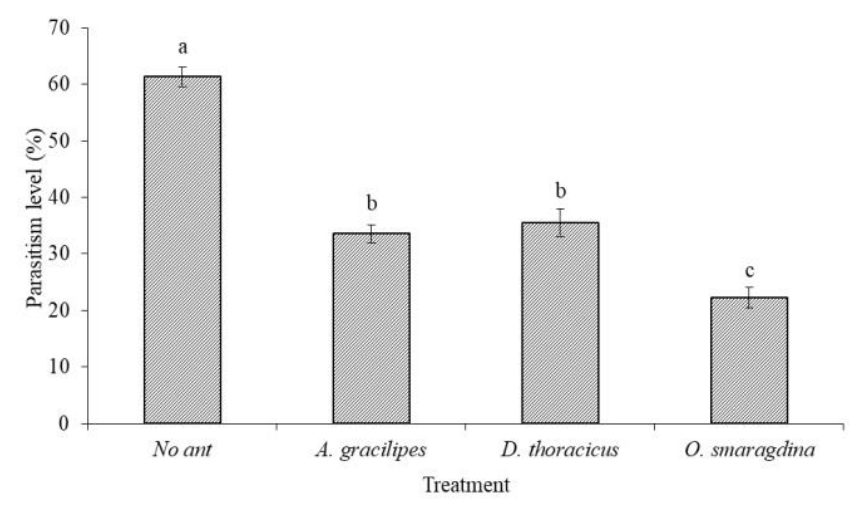

Figure 1. Parasitism rate $(\mathrm{x} \pm \mathrm{SE})$ of $P$. manihoti by parasitoid $A$. lopezi after a 24-h exposure period to three ant species. Bars with different alphabets are significantly different at $\mathrm{p} \leq 0.05$
The disruptive effect of ant attendance on parasitism of cassava mealybugs as well as on other mealybug species has been previously reported by various authors. For example, Cudjoe et al. (1993) found that ants of three genera (Pheidole megacephala (Fabricius), Camponotus sp., Crematogaster sp.) reduced parasitism rates by $A$. lopezi to half, compared to the rates observed on mealybug colonies that were not attended by ants. Where ants were excluded experimentally by insecticide barriers, parasitism was $32 \%$, compared to only $10 \%$ in control. Similarly, Tanga et al. (2016) reported the percentage of parasitism of Rastrococcus iceryoides (Green) (Hemiptera: Pseudococcidae) by Anagyrus pseudococci Girault was significantly higher on ant-excluded plants $(87 \%)$ compared to ant-present plants $(52 \%)$. Number of Phenacoccus solenopsis Tinsley (Hemiptera: Pseudococcidae) which was successfully parasitized by Aenasius bambawalei Hayat (Hymenoptera: Encyrtidae) significantly lower in area with Tapinoma melanocephalum (Fabricius) (Hymenoptera: Formicidae) than without ants which were 20 and $66 \%$, respectively (Zhou et al. 2014).

Accordingly, the number of emerged A. lopezi wasps was significantly higher $\left(\mathrm{F}_{3,31}=12.01 ; \mathrm{P}<0.001\right)$ in the ant-excluded treatment, averaging 41.50 compared with those in the ant-present treatments, which were $\leq 25$ emerged parasitoids (Table 3). The lowest number of emerged parasitoids (17.2) was found in the treatment of $O$. smaragdina, significantly different from treatments of $A$. gracilipes and $D$. thoracicus. A similar result was reported by Mansour et al. (2012) who found a higher number of parasitoid Anagyrus cf. pseudococci and Leptomastix dactylopii Howard (Hymenoptera: Encyrtidae) emerged in the ant-excluded treatment than in the ant-present treatment. The offspring sex ratio of $A$. lopezi was not significantly different $\left(\mathrm{F}_{3,31}=1.71 ; \mathrm{P}=0.15\right)$ between the ant-excluded and ant-present treatments. In all treatments, the sex ratio was around $50 \%$. This might indicate that presence of ants did not interfere with the mating activities of the parasitoids. Campos et al. (2006) also found that the offspring sex ratio of parasitoids, A. pseudococci, and $L$. dactylopii, was not altered by the presence of ant Lasius niger (Latreille). In contrast, Tanga et al. (2016) reported that offspring sex ratio of parasitoid $A$. pseudococci was more female-biased in the ant-excluded treatment compared to the ant-tended treatments, and they attributed this to the frequency of physical interference by ants.

Table 3. Number $(\mathrm{x} \pm \mathrm{SE})$ of $A$. lopezi emerged and its sex ratio after $24 \mathrm{~h}$ exposure period to third instar nymphs of $P$. manihoti in the ants-present and ant-excluded treatments

\begin{tabular}{lccc}
\hline Treatment & No. of mealybugs offered & No. of emerged parasitoids & Sex ratio $(\%$ female) \\
\hline Ant-excluded & 100 & $41.50 \pm 3.85 \mathrm{a} *$ & $52.53 \pm 1.64 \mathrm{a}$ \\
A. gracilipes & 100 & $25.00 \pm 2.02 \mathrm{~b}$ & $51.27 \pm 2.05 \mathrm{a}$ \\
D. thoracicus & 100 & $23.87 \pm 1.36 \mathrm{bc}$ & $51.07 \pm 2.06 \mathrm{a}$ \\
O. smaragdina & 100 & $17.12 \pm 1.23 \mathrm{c}$ & $56.10 \pm 3.53 \mathrm{a}$
\end{tabular}

Note: *Different alphabets within the same column are significantly different at $\mathrm{p} \leq 0.05$ 


\section{Attack behavior of ants and response of parasitoid wasps}

Ants act simultaneously as hemipteran mutualists and as predators (Calabuig et al. 2014). Our laboratory observation indicated that ants often showed aggressive behavior toward $A$. lopezi, whether they encounter the parasitoids on the host plant or the wall of the cage, and attempt to attack them. The number of attack attempts by O. smaragdina was significantly higher $\left(\mathrm{F}_{3,31}=3.94 ; \mathrm{P}=\right.$ 0.004 ) than those by $D$. thoracicus (Figure 2). Anytime approaching parasitoid, $O$. smaragdina usually extended the mandibles. We have once observed $O$. smaragdina preying on the parasitoid wasp. Among the three ant species tested in our study, $O$. smaragdina attendance resulted in the greatest disruption of parasitism, followed by $A$. gracilipes, while $D$. thoracicus resulted in the least disruption. Oecophylla smaragdina is generally aggressive in nature (Forbes and Northfield 2017; Nalini and Manickavasagam 2019) such as African weaver ant, Oecophylla longinoda Latreille (Tanga et al. 2016). Oecopylla spp. are known as predator of other arthropods of various sizes (Thurman et al. 2019). They use a strong mandible to capture and kill parasitoids. Tanga et al. (2016) suggested that the presence of $A$. longinoda has a detrimental effect on the abundance, reproductive success, and possibly oviposition strategy of parasitoid $A$. pseudococci. Several other species of ants have also been reported to be able to attack and kill parasitoid wasps, so their presence can reduce parasitism (Buckley and Gullan 1991; Mgocheki and Addison 2009; Liu et al. 2020). Daane et al. (2007) reported low parasitism rates for Pseudaphycus flavidulus (Brethes) when it parasitized Pseudococcus viburni (Signoret) in the presence of ant Linepithema humile (Mayr). Hence, ant-exclusion has potential as a sustainable pest management strategy for certain crops (Vanek and Potter 2010).

The parasitoids avoided close encounters with ants, mostly (76\%), by changing their walking direction (Figure 3 ). When attacked, the parasitoids avoided being caught by flying away (22\%) or jumping away (6\%). A small proportion of parasitoids (4\%) ignored the presence of ants and continued with the oviposition activities. The latter was especially found in the treatment with the non-aggressive ants D. thoracicus. In our laboratory experiments, ant especially $O$. smaragdina often attacked $A$. lopezi forcing to fly off the plant before finding their host nymphs. Thus, ant presence significantly reduced the time parasitoids spent on plants, resulting in reduced parasitism of $P$. manihoti on plants with ants relative to those without ants. However, even though ants interfered with the searching and ovipositing behavior of $A$. lopezi, they rarely caught or killed any parasitoid during experiments. The parasitoids were always able to avoid being caught by running, jumping, or flying away. It seems that the decreased parasitism of $P$. manihoti in plants with ants was not caused by parasitoid ant-induced mortality but by behavioral changes induced by the aggressive behavior of ants. When encountering to the ants in a host plant, parasitoid prefers to avoid by jumping, running away, and often flying away from plants. Avoidance behavior of parasitoids from being attacked by ants was also reported for other species e.g., A. pseudococci (Tanga et al. 2016), $H$. shuvakhinae (Liere and Perfecto 2008), and $L$. dactylopii (Campos et al. 2006). Consequently, parasitoids that abandoned oviposition and kept away from mealybugs to avoid ants will have a limited number of eggs that could be laid into the hosts.

\section{Implication}

Since 2010, the cassava mealybug has been rapidly spreading throughout Indonesia, as predicted previously by Yonow et al. (2017). Field observation indicated that higher plant damage was always associated with the abundance of ants (Fanani et al. 2019). Ant disruption of parasitoids of mealybugs is primarily an indirect relationship resulting from their interest in associated honeydew, which constitutes an important food resource for ants. Ants reduced mealybug parasitism through the act of disturbing parasitoid oviposition activity (Liere and Perfecto 2008). Therefore, even if ants do not often directly attack parasitoids, their presence can significantly reduce the parasitism percentage.

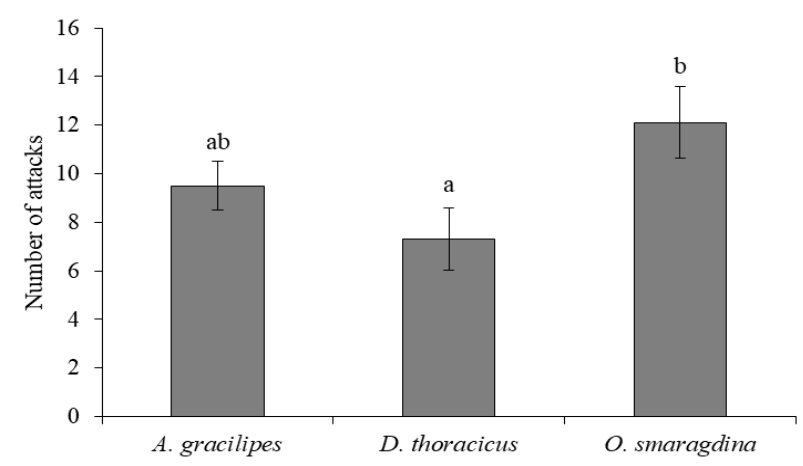

Figure 2. Number $(x \pm S E)$ of attack attempts by three ant species against parasitoid, A. lopezi for $1 \mathrm{~h}$ observation. Bars with different alphabet are significantly different at $\mathrm{p} \leq 0.05$

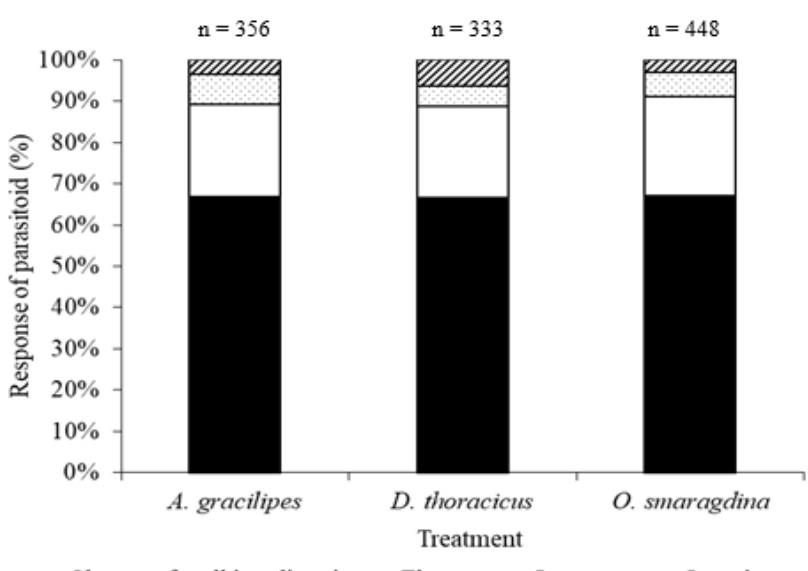

- Change of walking direction $\square$ Fly away $\square$ Jump away $\square$ Ignoring

Figure 3. Response of parasitoid A. lopezi to avoid encounters and attacks by three ant species for $1 \mathrm{~h}$ observation $(\mathrm{n}=$ frequency of encounters and attacks) 
Our laboratory data suggest that weaver ant $(O$. smaragdina) was very aggressive and had a greater negative effect on biological control of $P$. manihoti than the other two species. However, O. smaragdina was rarely found on cassava plants. They confined to making a nest on tree canopies (Itterbeeck et al. 2015). Hence, their impact might be significant if cassava fields are located adjacent to trees having the ant nests. Based on their consistent attendance, and given their invasive nature and wide distribution, A. gracilipes is the most likely to influence biological control of mealybugs, present a serious threat to the biological control of hemipteran pests like the cassava mealybug (Hoffmann 2015). In agricultural areas they nest underground, predominantly in an open area (Hoffmann 2015), thereby posing a serious threat to mealybug parasitoids. However, their impact on mealybug biological control is limited to drier regions as they appear to be negatively affected by flooding (Addison and Samways 2000). Overall, Mgocheki and Addison (2009) considers parasitoid Anagyrus sp. as sensitive to ants, thereby greatly reducing their potential as biological control agents (Martinez-Ferrer et al. 2003). Despite this ant interference, mealybug populations in the cassava fields having parasitoid A. lopezi such as in various location in Java (Fanani et al. 2019) were generally below damaging level, as also occurred in Africa (Cudjoe et al. 1993) and several countries in Southeast Asia (Le et al. 2018; Thancharoen et al. 2018; Wyckhuys et al. 2018b).

In conclusion, our laboratory studies provide several lines of evidence to indicate that the attendance of ants, especially $O$. smaragdina and $A$. gracilipes, on the cassava plants will likely reduce the effectiveness of the introduced parasitoid, A. lopezi in controlling the cassava mealybugs in the fields. However, since cassava plant is generally tolerant to foliar damage by the mealybugs, there will be no need to control the ant population in cassava fields.

\section{ACKNOWLEDGEMENTS}

This work was financially supported by the Ministry of Research, Technology, and Higher Education of the Republic of Indonesia under the Program Magister menuju Doktor untuk Sarjana Unggul (PMDSU).

\section{REFERENCES}

Abduchalek B, Rauf A, Pudjianto. 2017. Cassava mealybug, Phenacocccus manihoti Matile-Ferrero (Hemiptera: Pseudococcidae) Geographic distribution in Java and initiation of biological control. J Trop Plant Pests Dis 17: 1-8. [Indonesian]

Abram PK, Brodeur J, Urbaneja A, Tena A. 2019. Nonreproductive effects of insect parasitoids on their hosts. Ann Rev Entomol 64: 259276.

Addison P, Samways MJ. 2000. A survey of ants (Hymenoptera: Formicidae) that forage in the vineyards of the Western Cape Province, South Africa. Afr Entomol 8: 251-260.

Adriani E, Rauf A, Pudjianto. 2016. Encapsulation rates of parasitoid Anagyrus lopezi (De Santis) (Hymenoptera: Encyrtidae) by cassava mealybug, Phenacoccus manihoti Matile-Ferrero (Hemiptera: Pseudococcidae). Indonesian J Entomol 13 (3): 147-155. [Indonesian]
Bellotti A, Campo BVH, Hyman G. 2012. Cassava production and pest management: Present and potential threats in a changing environment. Trop Plant Biol 5: 39-72.

Beltra AA, Soto A, Tena A. 2015. How a slow-ovipositing parasitoid can succeed as a biological control agent of the invasive. Biol Control 60: 473-484.

Buckley R, Gullan P. 1991. More aggressive ant species (Hymenoptera: Formicidae) provide better protection for soft scales and mealybugs (Homoptera: Pseudococcidae). Biotropica 23 (3): 282-286.

Calabuig A, Garcia-Mari F, Pekas A. 2014. Ants affect the infestation levels but not the parasitism of honeydew and non-honeydew producing pests in citrus. Bull Entomol Res 194: 405-417.

Calabuig A, Garcia-Mari F, Pekas A. 2015. Ants in citrus: Impact on the abundance, species richness, diversity and community structure of predators and parasitoids. Agric Ecosyst Environ 213: 178-185.

Campos JM, Martinez-Ferrer MT, Fores V. 2006. Parasitism disruption by ants of Anagyrus pseudococci (Girault) and Leptomastix dactylopii Howard (Hymenoptera: Encyrtidae), two parasitoids of the citrus mealybug Planococcus citri (Risso) (Homoptera: Pseudococcidae). IOBC WPRS Bull 29 (3): 33-46.

Carabali-Banguero DJ, Wyckhuys KAG, Montoya-Lerma J, Kondo T, Lundgren JG. 2013. Do additional sugar sources affect the degree of attendance of Dysmicoccus brevipes by the fire ant Solenopsis geminate? Entomol Exp Appl 148: 65-73.

Cebolla R, Vanaclocha P, Urbaneja A, Tena A. 2018. Overstinging by hymenopteran parasitoids causes mutilation and surplus killing of hosts. J Pest Sci 91: 317-339.

Cheng SJ, Zeng L, Xu YJ. 2015 Mutualism between fire ants and mealybugs reduces lady beetle predation. J Econ Entomol 108: 15601569 .

Chong KF, Lee CY. 2010. Inter- and intraspecific aggression in the invasive longlegged ant (Hymenoptera: Formicidae). J Econ Entomol 103 (5): 1775-1783.

Cudjoe AR, Neuenschwander P, Copland MJW. 1993. Interference by ants in biological control of cassava mealybug Phenacoccus manihoti (Hemiptera: Pseudococcidae) in Ghana. Bull Entomol Res 83: 15-22.

Daane KM, Sime KR, Fallon J, Cooper ML. 2007. Impacts of Argentine ants on mealybugs and their natural enemies in California's coastal vineyards. Ecol Entomol 32: 583-596.

Detrain C, Verheggen FJ, Diez L, Wathelet B, Haubruge E. 2010. Aphidant mutualism: how honeydew sugars influence the behaviour of ant scouts. Physiol Entomol 35: 168-174.

Essien, Anietie R, Odebiyi, Adebayo J, Ekanem, Sunday M. 2013. Alternate host plant of Phenacoccus manihoti Matile Ferrero (Homoptera: Pseudococcidae), the cassava mealybug. J Agric Environ Manag 2 (12): 457-466.

Fanani MZ, Rauf A, Maryana N, Nurmansyah A, Hindayana D. 2019. Geographic distribution of the invasive mealybug Phenacoccus manihoti and its introduced parasitoid Anagyrus lopezi in parts of Indonesia. Biodiversitas 20 (12): 3751-3757.

Feng DD, Michaud JP, Li P, Zhou ZS, Xu ZF. 2015. The native ant, Tapinoma melanocephalum, improves the survival of an invasive melalybug, Phenacoccus solenopsis, by defending it from parasitoids. Sci Rep 5: 15691

Forbes SJ, Northfield TD. 2017. Oecophylla smaragdina ants provide pest control in Australian cacao. Biotropica 49 (3): 328-336.

Freitas JDD, Rossi MN. 2015. Interaction between trophobiont insects and ants: the effect of mutualism on the associated arthropod community. J Insect Conserv 19: 627-638.

Graziosi I, Minato N, Alvarez E, Ngo DT, Hoat TX, Aye TM, Pardo JM, Wongtiem P, Wyckhuys KAG. 2016. Emerging pests and diseases of Southeast Asia cassava: a comprehensive evaluation of geographic priorities, management options and research needs. Pest Manag Sci 72: 1071-1089.

Hagenbucher S, Wäckers FL, Romeis J. 2014. Aphid honeydew quality as a food source for parasitoids is maintained in Bt cotton. PloS ONE 9 (9): e107806. DOI: 10.1371/journal.pone.0107806.

Heidari M, Jahan MA. 2000. Study of ovipositional behavior of Anagyrus pseudococci a parasitoid of mealybugs. J Agr Sci Tech 2: 49-53.

Hoffmann BD. 2015. Integrating biology into invasive species management is a key principle for eradication success: the case of yellow crazy ant Anoplolepis gracilipes in northern Australia. Bull Entomol Res 105: 141-151.

Itterbeeck JV, Sivongxay N, Praxaysombath B, van Huis A. 2015. Location and external characteristics of the Oecophylla smaragdina queen nest. Insectes Sociaux 62: 351-356. 
Jia Yj, Liu TX. 2018. Dynamic host-feeding and oviposition behavior of an aphid parasitoid Aphelinus asychis. BioControl 63: 532-542.

Kaser JM, Nielsen AL, Abram PK. 2018. Biological control effects of non-reproductive host mortality caused by insect parasitoids. Ecol Appl 28 (4): 1081-1092.

Le TTN, Graziosi I, Cira TM, Gates MW, Parker L, Wyckhuys KAG. 2018. Landscape context does not constrain biological control of Phenacoccus manihoti in intensified cassava systems of southern Vietnam. Biol Control 121: 129-139.

Liere H, Perfecto I. 2008. Cheating on a mutualism: Indirect benefits of ant attendance to a coccidophagous coccinellid. Environ Entomol 37: 143-149.

Liu Y, Xu C, Li Q, Zhou A. 2020. Interference competition for mutualism between ant species mediates ant-mealybug associations. Insects 11 (2): 91.

Mansour R, Suma P, Mazzeo G, La Pergola A, Pappalardo V, Lebdi KG, Russo A. 2012. Interactions between the ant Tapinoma nigerrimum (Hymenoptera: Formicidae) and the main natural enemies of the vine and citrus mealybugs (Hemiptera: Pseudococcidae). Biocont Sci Tech 22 (5): 527-537.

Martinez-Ferrer MF, Grafton-Cardwell EE, Shorey HH. 2003. Disruption of parasitism of the California red scale (Homoptera: Diaspididae) by three ant species (Hymenoptera: Formicidae). Biol Control 26: 279286.

Mgocheki N, Addison P. 2009. Interference of ants (Hymenoptera: Formicidae) with biological control of the vine mealybug Planococcus ficus (Signoret) (Hemiptera: Pseudococcidae). Biol Control 49: 180-185.

Migani V, Ekesi S, Merkel K, Hoffmeister T. 2017. At lunch with a killer The effect of weaver ants on host-parasitoid interactions on mango. PLoS ONE 12 (2): e0170101. DOI: 10.1371/journal.pone.0170101.

Muniappan R, Shepard BM, Watson GW, Carner GR, Rauf A, Sartiami D, Hidayat P, Afun JVK, Goergen G, Rahman AKMZ. 2011. New records of invasive insects (Hemiptera: Sternorrhyncha) in Southern Asia and West Africa. J Agr Urban Entomol 26 (4): 167-174.

Nalini T, Manickavasagam S. 2019. Influence of weaver ant, Oecophylla smaragdina Fabricius (Hymenoptera: Formicidae) on mealybug parasitism by encyrtids (Chalcidoidea: Encyrtidae). J Biol Cont 33 (3): 303-306

Navarrete B, McAuslane H, Deyrup M, Pena JE. 2013. Ants (Hymenoptera: Formicidae) associated with Diaphorina citri (Hemiptera: Liviidae) and their role in its biological control. Fla Entomol 96 (2): 590-597.

Neuenschwander P, Madojemu E. 1986. Mortality of the cassava mealybug, Phenacoccus manihoti Mat.-Ferr. (Hom. Pseudococcidae), associated with an attack by Epidinocarsis lopezi (Hym., Encyrtidae). Mitt Schweiz Entomol Gesell 59: 57-62.

Neuenschwander P. 2001. Biological control of the cassava mealybug in Africa: A review. Biol Control 21 (3): 214-229.

Novgorodova TA. 2015. Organization of honeydew collection by foragers of different species of ants (Hymenoptera: Formicidae): Effects of colony size and species specificity. Eur J Entomol 112 (4): 688-697.

Parsa S, Kondo T, Winotai A. 2012. The cassava mealybug (Phenacoccus manihoti) in Asia: First records, potential distribution, and an identification key. PLoS ONE 7 (10): e47675. DOI 10.1371/journal.pone.0047675.

Sadeghi-Namaghi H, Amiri-Jami A. 2018. Success of aphid parasitoids and their hosts varies with ant attendance: A field study. Entomol Sci 21 (4): 406-411.
SAS. 2015. SAS 9.4 Procedures Guide. SAS Institute Inc, Cary, NC.

Shik JZ, Kay AD, Silverman J. 2014. Aphid honeydew provides a nutritionally balanced resource for incipient Argentine ant mutualists. Animal Behavior 95: 33-39.

Tanga CM, Ekesi S, Govender P, Nderitu PW, Mohamed SA. 2016. Antagonistic interactions between the african weaver ant Oecophylla longinoda and parasitoid Anagyrus pseudococci, potentially limits suppression of the invasive mealybug Rastrococcus iceryoides. Insects 7 (1): 1-17.

Tena A, Wäckers FL, Heimpel GE, Urbaneja A, Pekas A. 2016. Parasitoid nutritional ecology in a community context: the importance of honeydew and implications for biological control. Curr Opin Insect Sci 14: 100-104.

Thancharoen A, Lankaew S, Moonjuntha P, Wongphanuwat T, Sangtongpraow B, Ngoenklan R, Kittipadakul P, Wyckhuys KAG. 2018. Effective biological control of an invasive mealybug pest enhances root yield in cassava. J Pest Sci 91: 1199-1211.

Thurman JH, Northfield TD, Snyder WE. 2019. Weaver ants provide ecosystem services to tropical tree crops. Fron Ecol Evol 7: 120.

Vanek SJ, Potter DA. 2010. Ant-exclusion to promote biological control of soft scales (Hemiptera: Coccidae) on woody landscape plants. Environ Entomol 39 (6): 1829-1837.

Vilela AA, Del-Claro K. 2018. Effect of different ant species on the attendance of neighbouring hemipteran colonies and the outcomes for the host plant. J Nat Hist 52 (7-8): 415-428.

Watanabe S, Murakami Y, Hasegawa E. 2019. Effects of attending ant species on the fate of colonies of an aphid, Macrosiphonella yomogicola (Matsumura) (Homoptera: Aphididae), in an ant-aphid symbiosis. Entomol News 128 (4): 325-332.

Winotai A, Goergen G, Tamo M, Neuenschwander P. 2010. Cassava mealybug has reached Asia. Biocontrol News Inform 31: 10-11.

Wyckhuys KAG, Rauf A, Ketelaar J. 2014. Parasitoid introduced into Indonesia: Part of a region-wide campaign to tackle emerging cassava pests and deseases. Biocontrol News Inf 35 (4): 35-37.

Wyckhuys KAG, Wongtiem P, Rauf A, Thancharoen A, Heimpel GE, Le NTT, Fanani MZ, Gurr GM, Lundgren JG, Burra DD, Palao LK, Hyman G, Graziosi I, Le VX, Mock MJW, Tscharntke T, Wratten SD, Nguyen LV, You M, Lu Y, Ketelaar JW, Goergen G, Neuenschwander P. 2018a. Continental-scale suppression of an invasive pest by a host-specific parasitoid underlines both environmental and economic benefits of arthropod biological control. PeerJ 6: e5796. DOI: 10.7717/peerj.5796.

Wyckhuys KAG, Zhang W, Prager SD, Kramer DB, Delaquis E, Gonzalez CE, van der Werf W. 2018b. Biological control of an invasive pest eases pressures on global commodity markets. Environ Res Lett 13: 1-13.

Xu C, Li Q, Qu X, Chen J, Zhou A. 2020. Ant-hemipteran association decreases parasitism of Phenacoccus solenopsis by endoparasitoid Aenasius bambawalei. Ecol Entomol 45 (2): 290-299.

Yonow T, Kriticos DJ, Ota N. 2017. The potential distribution of cassava mealybug (Phenacoccus manihoti), a threat to food security for the $\begin{array}{lllll}\text { poor. PLoS ONE 12 (3): } & \text { e0173265. DOI: }\end{array}$ 10.1371/journal.pone.0173265.

Zhou AM, Liang GW, Zeng L, Xu YJ. 2014. Interactions between a ghost ant and the solenopsis mealybug: The case of Tapinoma melanocephalum (Hymenoptera: Formicidae) and Phenacoccus solenopsis (Hemiptera: Pseudococcidae). Fla Entomol 97 (4): 14741480 